Int. J. Dev. Biol. 50: 233-243 (2006)

doi: $10.1387 / \mathrm{ijdb} .052041 \mathrm{sg}$

\title{
Biophysical regulation during cardiac development and application to tissue engineering
}

\author{
SHARON GERECHT-NIR ${ }^{1}$, MILICA RADISIC ${ }^{2}$, HYOUNGSHIN PARK¹, CHRISTOPHER CANNIZZARO', \\ JAN BOUBLIK ${ }^{3}$, ROBERT LANGER ${ }^{1}$ and GORDANA VUNJAK-NOVAKOVIC*,4 \\ ${ }^{1}$ Harvard-MIT Division for Health Sciences and Technology, Massachusetts Institute of Technology, Cambridge, MA, USA, \\ 2 Institute of Biomaterials and Biomechanical Engineering and Dept. Chemical Engineering \& Applied Chemistry, University of Toronto, \\ Ontario, Canada, ${ }^{3}$ Institute of Health and Biomedical Innovation, Queensland University of Technology, Brisbane, Australia and \\ ${ }^{4}$ Dept. Biomedical Engineering, Columbia University, New York, USA
}

\begin{abstract}
Tissue engineering combines the principles of biology, engineering and medicine to create biological substitutes of native tissues, with an overall objective to restore normal tissue function. It is thought that the factors regulating tissue development in vivo (genetic, molecular and physical) can also direct cell fate and tissue assembly in vitro. In light of this paradigm, tissue engineering can be viewed as an effort of "imitating nature". We first discuss biophysical regulation during cardiac development and the factors of interest for application in tissue engineering of the myocardium. Then we focus on the biomimetic approach to cardiac tissue engineering which involves the use of culture systems designed to recapitulate some aspects of the actual in vivo environment. To mimic cell signaling in native myocardium, subpopulations of neonatal rat heart cells were cultured at a physiologically high cell density in three-dimensional polymer scaffolds. To mimic the capillary network, highly porous elastomer scaffolds with arrays of parallel channels were perfused with culture medium. To mimic oxygen supply by hemoglobin, culture medium was supplemented with an oxygen carrier. To enhance electromechanical coupling, tissue constructs were induced to contract by applying electrical signals mimicking those in native heart. Over only eight days of cultivation, the biomimetic approach resulted in tissue constructs which contained electromechanically coupled cells expressing cardiac differentiation markers and cardiac-like ultrastructure and contracting synchronously in response to electrical stimulation. Ongoing studies are aimed at extending this approach to tissue engineering of functional cardiac grafts based on human cells.
\end{abstract}

KEY WORDS: myocardium, oxygen, interstitial flow, physical signals, bioreactor

\section{Introduction}

\section{Cardiovascular disease}

Cardiovascular disease is the most frequent cause of death in the western world. The main contributor is myocardial infarction, affecting more than one million Americans each year. Heart disease and stroke, the principal components of cardiovascular disease, are the first and the third leading cause of death in the U.S., accounting for nearly $40 \%$ of all deaths. Congenital heart defects, which occur in nearly 14 of every 1000 newborn children (Oberpenning et al., 1999), are the most common congenital defects (Ogawa et al., 2004, Ohji et al., 1995). In the course of remodelling, necrotic cardiomyocytes are lost, during a process accompanied by the formation of granulation tissue. Simulta- neously, neovascularization in the peri-infarcted area takes place, to support the survival of surrounding hypertrophic cardiomyocytes and prevent further cell loss caused by apoptosis (Cheng et al., 1996). Finally, remodelling leads to the formation of fibrous scar tissue, which is non-contractile and may expand, thereby causing further cardiac impairment (Braunwald and Pfeffer, 1991). Adult mammalian cardiomyocytes terminate their cell cycle during differentiation and cannot be regenerated.

Treatment options for congestive heart failure include pharmacological, interventional and surgical therapeutic methods, all of which have limited ability to prevent ventricular remodelling, a common cause of ventricular dilatation and heart failure (Braunwald and Pfeffer, 1991). Given the high morbidity and mortality rates associated with congestive heart failure, shortage of donor hearts

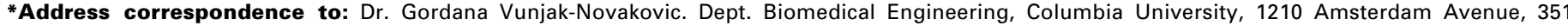
Engineering Terrace, Mail code 8904, New York NY 10027, USA. e-mail: gv2131@columbia.edu
} 
for transplantation, complications and long-term failure of transplanted organs resulting from immunosuppression, novel therapeutic modalities for improving cardiac function and preventing heart failure are in critical demand (Hunt, 1998, Lee and Makkar, 2004).

\section{Stem cell therapy}

Repair of damaged or ischemic cardiac tissue may be achieved by transplantation of healthy, functional and propagating cells that are capable of restoring tissue viability and function. Transplantation of exogenous adult and embryonic stem cells into damaged myocardium improved myocardial function by reducing ventricular remodelling, providing a source of new myocytes and improving vascular supply. Transplanted cells include embryonic, fetal and neonatal cardiomyocytes (Leor et al., 1996, Scorsin et al., 1996), skeletal myoblasts (Menasche, 2003, Taylor et al., 1998), mesenchymal stem cells from bone marrow (Orlic et al., 2001) and cardiomyocytes derived from human embryonic stem cells (Kehat et al., 2004).

The use of human fetal cardiomyocytes for cardiac repair has been constrained by ethical issues and the limited supply of these cells. In addition, it is not clear whether intra-cardiac grafts derived from fetal cardiomyocytes can integrate in a tissue-specific and functional manner into the host myocardium. Intra-cardiac grafts containing these cells remained isolated and were unable to differentiate into adult cardiomyocytes (Etzion et al., 2001). A recent clinical study showed successful transplantation of autologous skeletal muscle cells into myocardial scar tissue during bypass surgery that resulted in increased wall thickness, improved contractility and vascularisation (Menasche et al., 2001). However, four out of ten patients developed severe arrhythmias requiring implantation of automated cardioverter defibrillators. This may be due to ectopic electrical activity of the transplanted skeletal muscle cells, which do not integrate into the host myocardium via functional cellular contacts.

Recent advances in stem cell research now offer exogenous

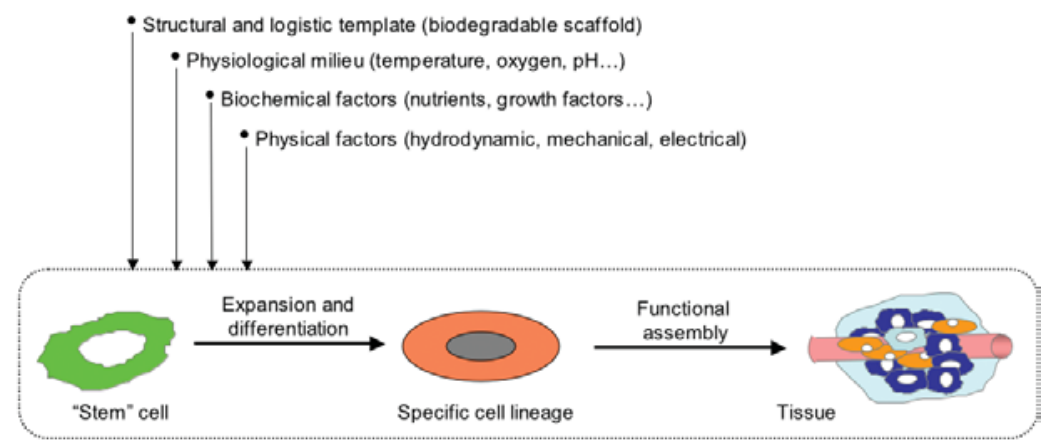

Fig. 1. Developmental paradigm. Tissue development and remodeling, in vivo and in vitro, involves the proliferation and differentiation of stem/progenitor cells and their subsequent assembly into a tissue structure. Cell function and the progression of tissue assembly depend on: (a) the availability of a structural and logistic template for cell attachment and tissue formation, (b) the maintenance of physiological conditions in cell/ tissue environment, (c) exchange of nutrients, oxygen, metabolites and growth factors and (d) presence of physical regulatory factors. Reproduced with permission from Radisic M, Obradovic B. and Vunjak-Novakovic G. (2005). Functional tissue engineering of cartilage and myocardium: bioreactor aspects. In Scaffolding in Tissue Engineering (Eds. P.X. Ma and J. Elisseeff). Marcel Dekker, pp. 491-520. stem cells as an alternative cell source for the treatment of heart failure. To be considered a stem cell, a cell must exhibit at least the following characteristics: ( $\chi$ the ability to self-renew for long periods of time; (i) a single cell division will produce at least one but possibly two daughter cells identical to the cell of origin; (iii) potential to differentiate into the specialized cells, which constitute and repopulate bodily tissues and organs; (iv) capability of sublineage differentiation of each single cell; ( $V$ ) and ability of each single cell to form a clone (i.e., a line of genetically identical cells). In most adult tissues, stem or progenitor cells are mobilized in response to environmental stimuli, but these cells can form only a limited number of cell types. In early mammalian embryos at the blastocyst stage, the inner cell mass is pluripotent. Therefore, the identification, derivation and characterization of human embryonic stem cells (hESCs) may open the door to the rapidly progressing field of therapeutic cell transplantation.

\section{Tissue engineering}

Tissue engineering combines the principles of biology, engineering and medicine to create functional grafts capable of repairing native tissue following a congenital deformity, disease or trauma. The overall objective of all tissue engineering is the restoration of normal tissue function. In general, a lost or damaged tissue would be best replaced by an engineered graft that can reestablish appropriate structure, composition and cell signaling inherent to the native tissue. In the cardiovascular system, an optimal replacement tissue would need to integrate with the native heart muscle and re-establish the cell-cell signaling and contractile function. For clinical relevance, engineered cardiac constructs should be thick and compact, contain high density of metabolically active and well differentiated cardiomyocytes and contract synchronously in response to electrical stimulation. Moreover, only grafts that are already vascularized or have a capacity to establish functional vasculature immediately following implantation are likely to survive, integrate and function in vivo. Engineered constructs of such high fidelity can also serve as physiologically relevant yet controllable models for basic studies on tissue development and cell function in response to genetic alterations, drugs, hypoxia and physical stimuli.

Cardiac constructs that expressed distinct structural and functional features characteristic of differentiated myocardium have been engineered in vitro starting from neonatal rat cardiac myocytes cultured in collagen gels, fibers and sponges (Akins et al., 1999, Eschenhagen et al., 1997, Fink et al., 2000, Kofidis et al., 2002, Li et al., 1999, Li et al., 2000, Radisic et al., 2003, Radisic et al., 2004d, van Luyn et al., 2002, Zimmermann et al., 2000, Zimmermann et al., 2002a), alginate sponges (Leor et al., 1996, Leor et al., 2000), polyglycolic acid meshes (Bursac et al., 1999, Carrier et al., 1999, Papadaki etal., 2001) or by stacking confluent cell monolayers into thin pulsatile sheets (Shimizu etal., 2002). In many cases, bioreactors were used to enhance mass transport of nutrients (most critically oxygen) and metabolites to and from the cells (e.g., (Bursac et al., 1999, Carrier et al., 1999, Papadaki et al., 2001, Radisic etal., 2004d)) and to apply dynamic mechanical stretch (Eschenhagen et al., 1997) or electrical stimulation (Radisic etal., 2004c) to enhance electro-mechani- 
cal cell coupling. Overall, the clinical utility of tissue engineering will likely depend on our ability to replicate the site-specific properties of the tissue being replaced across different size scales and establish the specific differentiated cell phenotype, the composition, architectural organization and biomechanical properties of the tissue and provide the continuity and strength of the interface with the neighboring host tissues.

In this article, we discuss a "biomimetic" approach to tissue engineering of functional myocardium that is based on principles derived from developmental biology. We first review some relevant aspect of cardiovascular development in utero. Then we focus on engineering of thick, compact and functional cardiac tissue constructs starting from dissociated, already differentiated heart cells (neonatal rat heart model). Finally, we discuss the biological and engineering aspects of the application of the same general approach to engineering of vascularized cardiac grafts starting from human stem cells.

\section{Cardiovascular development}

\section{Overview}

The myocardium (cardiac muscle) is a highly differentiated tissue composed of cardiac myocytes and fibroblasts with a dense supporting vasculature (consisting of endothelial cells) and collagen-based extracellular matrix (ECM). The myocytes form a three-dimensional synctium that enables propagation of electrical signals across specialized intracellular junctions to generate coordinated mechanical contractions that pump blood forward. Only $20-40 \%$ of the cells in the heart are cardiac myocytes but they occupy $80-90 \%$ of the heart volume. The average cell density in the native rat myocardium is on the order of $5 \times 10^{8}$ cells $/ \mathrm{cm}^{3}$. Morphologically, intact cardiac myocytes have an elongated, rod shaped appearance. The contractile apparatus of cardiac myocytes consists of sarcomeres arranged in parallel. Metabolic requirements of the cells are supported by the high density of mitochondria and electrical signal propagation is provided by specialized intercellular connections, gap junctions (Brilla et al., 1995, MacKenna et al., 1994).

The control of heart contractions is almost entirely self-contained. Groups of specialized cardiac myocytes (pacemakers), fastest of which are located in the sinoatrial node, drive periodic contractions of the heart. The majority of the cells in the myocardium are non-pacemaker cells and they respond to the electrical stimuli generated by pacemaker cells. Excitation of each cardiac myocyte is followed by an increase in the amount of cytoplasmic calcium that triggers mechanical contractions. The propagation of the electrical excitation through the tissue by ion currents in the extracellular and intracellular spaces results in synchronous contractions.

The circulatory system consisting of the heart, blood cells and an intricate system of blood vessels provides nourishment to the developing human embryo. It is the first functional unit in the developing vertebrate embryo, while the heart is the first functional organ (Gilbert et al., 2000). Morphological studies show that the early steps of heart formation are remarkably conserved among vertebrates, including humans, although, the timing of these developmental events differs among species (Fishman and Chien, 1997, Olson and Srivastava, 1996). The formation of a primitive tubular heart by the precardiac mesoderm is initiated between E7.5 and E8 in mouse and the first contraction of this primitive structure can be observed from E8.5 to E9 (Fishman and Chien, 1997). In humans, the heart primordium forms within a cardiogenic area located cranial and lateral to the brain. On day 19, angioblasts in the splanchnopleuric mesoderm respond to inductive signals from the endoderm to form lateral endocardial tubes and then during embryonic folding during the fourth week these vessels are translocated to the thoracic region, where they fuse to form the primitive heart tube. From week 5 to week 8 , the primitive heart tube undergoes folding, remodelling and septation to form the four-chambered heart. Sinistral looping positions the regions of the heart that will form the primitive atria and ventricles and raises the inflow vessels to the level of the outflow tracts (Larsen, 1998). Thus, although the heart is the first functional organ of the body, it does not begin to pump until the vascular system of the embryo has established its first circulatory loops. Rather than sprouting from the heart, blood vessels form independently and link up to the heart soon afterwards.

In the human embryo, the first blood vessels form within the yolk sac mesoderm in conjugation with blood cells on day 18 (Larsen, 1998). In the latter process, referred to as vasculogenesis, mesodermal angioblastic cysts fuse to form networks of angioblastic cords that expand, coalesce and invade embryonic tissues (Larsen, 1998 ) to create the arterial, venous and lymphatic channels. Blood vessels are also constructed by another process called angiogenesis which refers to the sprouting, remodelling and spreading of the primary network into a distinct capillary bed, arteries and veins

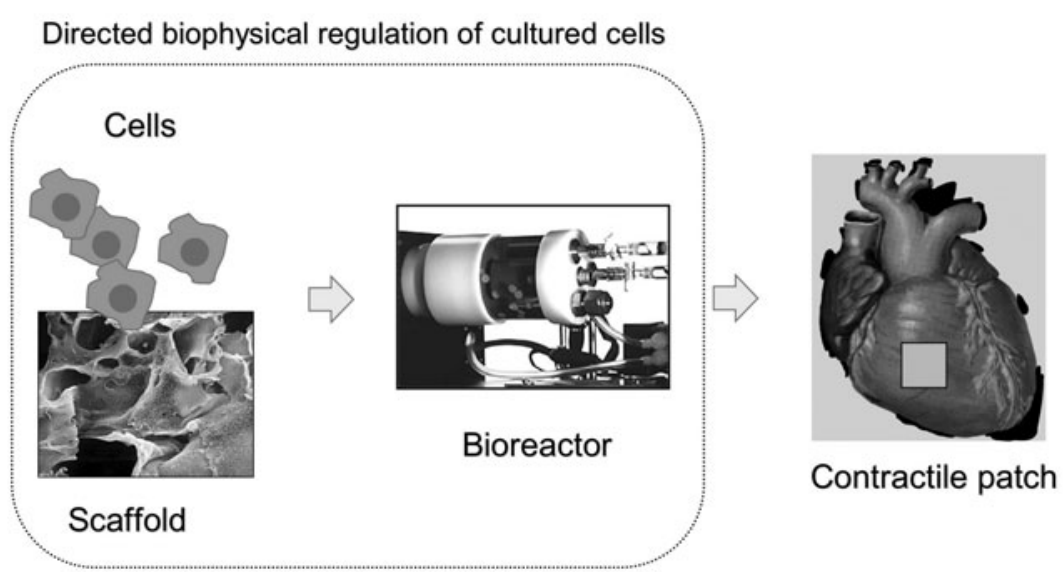

Fig. 2. Tissue engineering paradigm. The regulatory factors of cell differentiation and tissue assembly depicted in Fig. 1 can be utilized in vitro to engineer functional tissues by an integrated use of isolated cells, biomaterial scaffolds and bioreactors. The cells themselves (either differentiated or progenitor/stem cells seeded onto a scaffold and cultured in a bioreactor) carry out the process of tissue formation, in response to regulatory signals. The scaffold provides a structural, mechanical and logistic template for cell attachment and tissue formation. The bioreactor provides the environmental conditions and regulatory signals (biochemical and physical) that induce, enhance or at least support the development of functional tissue constructs. Reproduced with permission from Radisic M, Obradovic B. and Vunjak-Novakovic G. (2005). Functional tissue engineering of cartilage and myocardium: bioreactor aspects. In Scaffolding in Tissue Engineering (Eds. P.X. Ma and J. Elisseeff). Marcel Dekker, pp. 491-520. 
Dish

(25rpm)
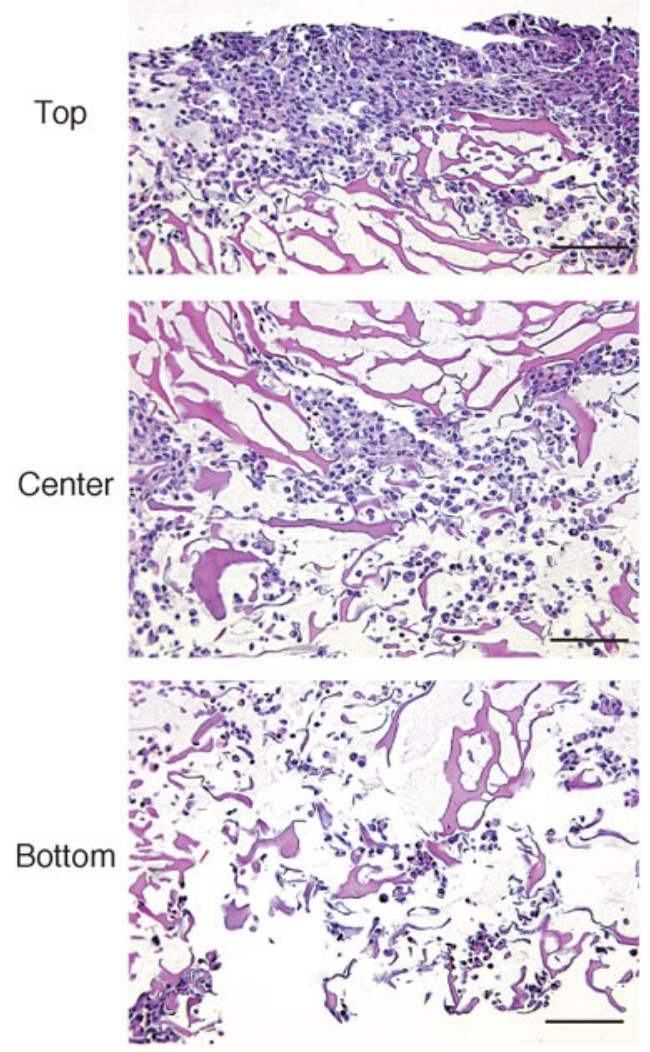

Perfusion

$(1.5 \mathrm{ml} / \mathrm{min})$
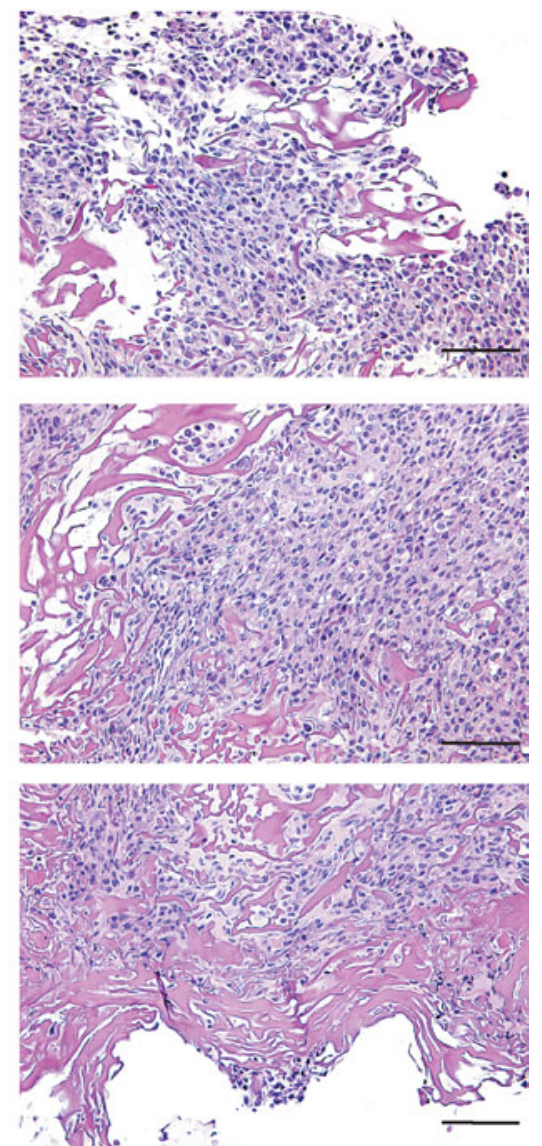

Fig. 3. Perfusion enables the establishment of physiological cell density throughout the construct volume. Cross-sections of constructs inoculated with 12 million cells and then transferred for a period of $4.5 \mathrm{~h}$ either into orbitally mixed dishes $(25 \mathrm{rpm}$, left) or into perfused cartridges $(1.5 \mathrm{ml} / \mathrm{min}$, right). The top, center and bottom areas of a $650 \mu \mathrm{m}$ wide strip extending

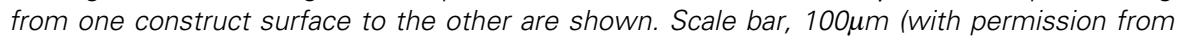
Radisic et al., Biotech. Bioeng 82: 403-414, 2003. Fig. 4).

(Risau, 1997). It is important to recognize that the capillary network of each organ arises within the organ itself and is not an extension from larger blood vessels (Gilbert et al., 2000).

\section{Regulation of cardiac development}

The generation of functional cardiomyocytes in embryos appears to be influenced by a combination of positive and negative induction signals produced from adjacent tissues (Antin et al., 1994, Lough and Sugi, 2000). In all vertebrates, the tubular heart undergoes a process know as rightward looping. The morphogenetic steps required to achieve looping are directed by molecular asymmetries that are found in and around the heart by the embryo left/right axial pathway (Harvey, 1998). In higher vertebrates, septal division of the chambers and formation of the valves, which involves endothelial cells, are essential steps leading to the formation of an integrated 4-chambered heart with separate venous and arterial poles. During the growth process of the cardiac epithelium, another distinct cell lineage, the migrating cardiac neuronal crest cells populate the heart through the outflow channel and contribute

to the formation of the great vessels and outflow septum.

Altogether, early cardiac development and specification requires spatial and temporal interactions of inductive tissue across germ layers, which generate bilateral heart primordia in the lateral mesoderm. This developmental process is exerted largely through precisely controlled processes of cell-cell, cell-ECM signaling and regulation of gene expression. It has been shown that extra-embryonic endoderm (the hypoblast) has the ability to induce cardiogenesis from cells in the epiblast by the presence of activin or transforming growth factor- $\beta$ (TGF- $\beta$ ). Later on in development, the anterior endoderm also induces the formation of cardiac mesoderm by various factors including activin A, fibroblast growth factor FGF1, FGF2, or FGF4, insulin and insulin-like growth factors (IGFs) (Antin et al., 1996, Sugi and Lough, 1995, Zhu et al., 1996) as well as bone morphogenetic proteins (BMPs) (Schultheiss et al., 1997). In addition to growth factors, Wnt proteins also take part in cardiogenesis. The Wnt signaling pathway mediates the inhibitory effect of the neural tube overlying the heart forming region (Climent et al., 1995).

Classical studies have mainly used morphological criteria and myocardial genes (e.g., actinin, desmin, myosin heavy chains, troponins) as markers of cardiac induction. Recent studies demonstrated that the earliest responses involve the induction of regulatory genes that encode specific transcription factors including of the NK homeodomain, GATA and T-box. The main representative of the NK homeodomain is $N k x-2.5$, which is expressed in the lateral plate mesoderm within the heart (Zaffran and Frasch, 2002). The importance of this transcription factor for cardiogenesis is evidenced by its expression as well as its interaction with other cardiogenic transcription factors such as the GATA super-family. Gata4/5/6are expressed in the precardiac mesoderm and developing heart simultaneously with Nkx2.5 while their expression includes the associated endodermal layer (Heikinheimo et al., 1994, Jiang and Evans, 1996, Laverriere et al., 1994). The role and involvement of T-box genes during heart development is less defined and relies mainly on heart defects carrying mutations in Tbx1 and Tbx5 (reviewed by Zaffran and Frasch, 2002).

The critical role of ECM remodeling in cardiac development has been recognized and the molecular factors responsible for this process are now being explored. Important components of cardiac ECM include structural and adhesive proteins such as collagen and fibronectin. Integrins, cell surface receptors that mediate cellular adhesion to the extracellular matrix, are signaling molecules that couple mechanical stimuli to functional responses which result in activation of various signal transduction pathways. Although most of the heart volume consists of cardiomyocytes, cardiac fibroblasts and endothelial cells account for the majority of the cells (Maly etal., 
2004). Cardiac fibroblasts are responsible in large part for production, organization and turnover of the ECM, thereby regulating the mechanotransduction of the heart.

The application of defined mechanical stimuli to cultured cardiac fibroblasts has been associated with ECM gene expression and growth factor production, release and/or bioactivity. Dynamic stretching of cardiac fibroblasts caused the activation of $\beta 1$-integrin dependent ERK and JNK pathways (MacKenna et al., 1998, Ross et al., 1998), as well as the expression of collagen III, fibronectin and TGF- $\beta 1$ (Gudi etal., 1998, MacKenna etal., 1998). Hence, the stretch-induced response is being transmitted to cardiomyocytes through autocrine or paracrine signaling and ECM remodeling. Changes in ECM structure and mechanics were suggested to alter the balance of forces that are transferred across the cell surface adhesion receptors that line the ECM to the internal supporting framework of the cell, the cytoskeleton (Ingber, 2002). Given the complex nature of the interstitial milieu of the working heart, additional research is needed to further our understanding of the role of mechanical stimuli in excess deposition of myocardial ECM. In particular, evidence of local mechanical control of tissue patterning awaits development of new methods for applying controlled stresses for real-time readout of cellular response.

The heart is the one of the few organs that has to function almost as soon as it is formed. The human heart begins to beat and to propel blood through the embryo and placenta on day 22 (Larsen, 1998). Cardiac function depends on the appropriate timing and synchronization of the mechanical contraction in various regions of the heart, as well as on achieving the appropriate heart rate. These properties are ensured through the hierarchical organization and electrical specialization of the cardiac conduction system, which is governed by the differential expression of cardiac ion channels in each component (Schram et al., 2002). Electrical excitation of the heart originates in the sinoatrial node, spreads through the atria to the atrioventricular node and then activates the ventricles through the specialized His-Purkinje system (Gepstein et al., 2004).

\section{Cardiac tissue engineering}

\section{Biomimetic approach}

It is increasingly recognized that cell function in vitro can be modulated by the same factors known to play a role during normal embryogenesis in vivo. Tissue development and remodeling, in vivo and in vitro, involves the proliferation and differentiation of stem/progenitor cells and their subsequent assembly into a tissue structure. In vivo, the processes of cell differentiation and tissue assembly are directed by multiple factors acting in concert and according to specific spatial and temporal sequences (Fig. 1). Some of the factors known to determine cell fate and the progression of tissue assembly include: (i)The availability of a structural and logistic template for cell attachment (during cell proliferation, differentiation into specific lineages and maturation) and subsequent tissue formation, (ii) The maintenance of physiological conditions in cell/tissue environment, (iii) Efficient transport of nutrients, oxygen, metabolites and growth factors between the cells and their environment and (iv) The presence of physical regulatory factors that play a role in cardiac development (hydrodynamic shear, electrical signals, mechanical stretch).

In vitro, biophysical regulation of cultured cells can be achieved by an integrated use of biomaterial scaffolds and bioreactors, with the general goal to recapitulate environmental factors present in vivo during normal cardiac development (Fig. 2). Both in vivoand in vitro, the cells are the actual "tissue engineers" and they function (proliferate, differentiate, mature) in response to genetic and environmental signals. In vitro, the biomaterial scaffold is designed to provide a structural and logistic template for cell attachment and tissue formation and to biodegrade at a controlled rate (ideally corresponding to the rate of tissue formation). The mechanical properties of the scaffold should ideally match those of the native tissue and the mechanical integrity should be maintained as long as necessary for the new tissue to mature and integrate. In the case of cardiac tissue engineering, it is important that the scaffold material is tough enough to allow handling, but soft and elastic enough to transmit mechanical forces and support synchronous contractions. In the same in vitromodel system, the bioreactoris designed to (a) maintain physiological milieu in the cell microenvironment ( $\mathrm{pH}$, temperature, concentration levels), (b) provide efficient mass transport of nutrients, oxygen and regulatory factors and (c) enable the application of physical regulatory signals.

The "biomimetic" approach to cardiac tissue engineering we developed involves the in vitro creation of immature but functional tissues by mimicking some of the key factors present in the native myocardium: high cell density with multiple cell types, convective diffusive oxygen transport through a capillary network and orderly excitation contraction coupling (Table 1)

\section{High cell density}

Because the native myocardium is composed of cardiac myocytes and fibroblasts with a dense supporting vasculature, at a cell density on the order of $10^{8}$ cells $/ \mathrm{cm}^{3}$, an engineered cardiac construct should ideally consist of the same cell subpopulations, at appropriate fractions and at a physiologic cell density. This is

TABLE 1

FACTORS GOVERNING CARDIAC TISSUE DEVELOPMENT IN VIVO THAT ARE INCORPORATED INTO THE DESIGN OF SYSTEMS FOR "BIOMIMETIC" TISSUE ENGINEERING IN VITRO

\begin{tabular}{lll} 
& In vivo & In vitro \\
\hline High cell density - Multiple cell types & High density $\left(1-5 \times 10^{8} \mathrm{cells} / \mathrm{cm}^{3}\right.$ & High density \\
& (Mandarim-de-Lacerda and Pereira, 2000) & $\left(0.5-1 \times 10^{8} \mathrm{cells} / \mathrm{cm}^{3}\right)$ \\
& Multiple cell types (myocytes, endothelial cells, fibroblasts) & Multiple cell types (myocytes, Fibroblasts) \\
Oxygen and nutrient supply & Convection and diffusion (vasculature) & Convection and diffusion in (medium perfusion) \\
Geometry & Capillary network & Channel array in the scaffold \\
Oxygen carrier & Hemoglobin & PFC Emulsion (Oxygent( $\left.{ }^{3}\right)$ \\
Excitation-contraction coupling & Electrical signal propagation & Electrical stimulation \\
& Ventricle contraction & Construct contraction \\
\hline
\end{tabular}


assumption is based on the need for cell coupling and cell-cell signaling and the fact that cardiac myocytes have very limited ability for proliferation, such that a lack of cells cannot be compensated by cell growth. This first requirement of "biomimetic" cardiac tissue engineering - high cell density - is critical and not easy to meet.

In our early studies, tissue constructs were formed by seeding neonatal rat ventricular cardiac myocytes onto fibrous scaffolds ( $11 \mathrm{~mm}$ in diameter $\times 2 \mathrm{~mm}$ thick, 5 million cells per scaffold) made of polyglycolic acid (material used to make resorbable surgical sutures) for 3 days in mixed flasks and then cultured with pulsatile flow of medium through the construct at an interstitial velocity of $35-500 \mu \mathrm{m} / \mathrm{s}$. Perfusion resulted in uniform distribution of cells expressing sarcomeric $\alpha$-actin and cardiac specific ultrastructural features (sarcomeres, gap junctions), but the cell density remained low due to the diffusional limitations of oxygen transport during seeding that resulted in substantial cell loss (Carrier et al., 2002a, Carrier et al., 2002b).

Cardiac myocytes, which are the most active cells in our body, seeded at a high density require efficient supply of nutrients and oxygen at all times during seeding and cultivation to maintain their viability. With this goal in mind, we developed a seeding technique that involves (a) rapid inoculation of cardiac myocytes into collagen sponges using Matrige $\mathrm{I}^{\mathrm{TM}}$ as a cell delivery vehicle and (b)

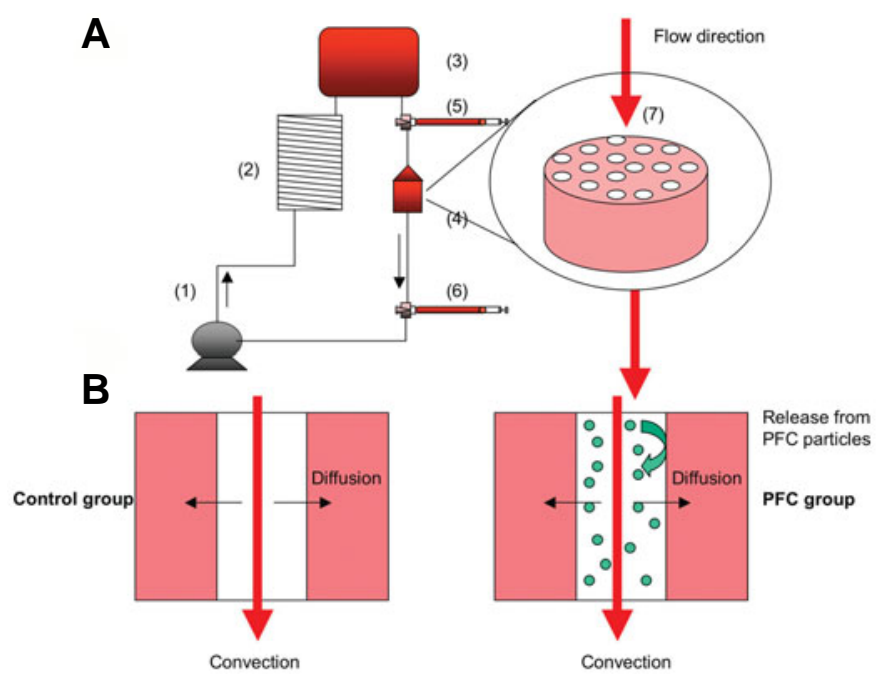

Fig. 4. Oxygen supply: medium perfusion, channeled scaffolds and oxygen carriers. (A) Perfusion loop. Channeled biorubber scaffolds (7) preconditioned with cardiac fibroblasts were seeded with cardiac myocytes and placed into perfusion cartridges (4) between two debubbling syringes $(5,6)$. Medium flow $(0.1 \mathrm{ml} / \mathrm{min})$ was provided by a multi-channel peristaltic pump (1) and gas exchange was provided by a coil of thin silicone tubing (2). Loops were placed in the $37^{\circ} \mathrm{C} / 5 \% \mathrm{CO}_{2}$ incubator vertically. (B) Modes of oxygen transport in the channeled construct perfused with culture medium include convection through the channel lumen and diffusion into the tissue space surrounding each channel. In regular culture medium (control group, shown on left) oxygen dissolved in the aqueous phase during gas exchange in the external loop is transported into the tissue phase and consumed by the cells. In culture medium supplemented by $10 \%$ perfluorocarbon (PFC) emulsion (PFC group, shown on right), oxygen is replenished within the tissue construct by the release of oxygen from the PFC particles into the culture medium phase. transfer of inoculated scaffolds into perfused cartridges with immediate establishment of the interstitial flow of culture medium. This way, cells are "locked" into the scaffold during a short (10 min) gelation period and evenly distributed by medium perfusion. Cell distributions in the top, center and bottom areas of a $0.65 \mu \mathrm{m}$ wide strip extending from one construct surface to the other are shown in Fig. 3. Constructs seeded in orbitally mixed dishes had most cells located in the $100-200 \mu \mathrm{m}$ thick layer at the top surface and only a small number of cells penetrated the entire construct depth (Fig. 3, left). Constructs seeded in perfusion exhibited high and spatially uniform cell density throughout the perfused volume of the construct (Fig. 3, right). Cell viability was indistinguishable from that measured for freshly isolated neonatal rat heart cells (Radisic et al., 2003). Clearly, medium perfusion during seeding was key for engineering thick constructs with high densities of viable cells.

\section{Cell sub-populations}

Native myocardium consists of approximately one third myocytes (terminally differentiated non-proliferating cells) and several other cell types, most of which are fibroblasts (proliferating cells). In a manner analogous to monolayer culture where fibroblasts are removed to prevent overgrowth, our early attempts to engineer myocardium utilized cells enriched for myocytes (80 to $90 \%$ ). The engineered tissue exhibited markers of cardiac differentiation and propagated electrical signals over macroscopic distances. However, cells did not align in parallel as in the native myocardium and the contractile response was not reported. In our recent studies, we explored if co-culture of cardiac myocytes with cardiac fibroblasts will enhance functional assembly of the engineered cardiac constructs by enabling scaffold remodeling and active cross-talk between cells. Cardiac myocytes were cultured on elastomer scaffolds either alone (CM), or as an un-separated cell population isolated from heart ventricles (US) or on scaffolds pretreated with cardiac fibroblasts (CM-CF).

After 7 days of cultivation, the CM-CF group had superior contractile properties (as evidenced by the highest amplitude of contraction and the lowest excitation threshold) and superior composition and morphology. The CM-CF group exhibited compact layers of elongated myocytes aligned in parallel, with fibroblasts located preferentially in the surface layer, while US and CM groups exhibited scattered and poorly elongated myocytes. Histology revealed the presence of collagen depositing fibroblasts (prolyl-4-hydroxylase) and the compact regions of myocytes surrounded by collagen (Mason's trichrome) in the pretreated group only. The presence of actively secreting fibroblasts, that created an environment supportive of tissue assembly upon addition of myocytes, appeared to be essential for improved properties in the pretreated group (Radisic et al., 2004b).

\section{Oxygen supply}

In a native heart, oxygen is supplied by diffusion from capillaries that are spaced $20 \mu \mathrm{m}$ apart (Rakusan and Korecky, 1982). The physical solubility of oxygen in plasma is low and the oxygen carrier hemoglobin increases total oxygen content of blood and therefore increases the mass of tissue that can be supported in a single pass of blood through the capillary network. Hemoglobin increases the amount of oxygen in blood by two orders of magnitude, such that the average oxygen concentration in arterial 
blood is $130 \mu \mathrm{M}$ and in the venous blood it is $54 \mu \mathrm{M}$ (Fournier, 1998). In engineered cardiac muscle, one can mimic blood flow through the capillary network by culturing cells on scaffolds that contain an array of channels perfused with culture medium. Channeled scaffolds provide a structural template in which myocytes and fibroblasts fill the scaffold pores and endothelial cells forming the capillary bed can be seeded to line the channel walls, thus providing two segregated compartments as in the native heart. Synthetic oxygen carriers, such as perfluorocarbons (PFCs), can be supplemented to culture medium in order to increase its oxygen-carrying capacity.

Conventional culture conditions resulted in the formation of cardiac-like tissue structures, but had substantial limitations. Fetal and neonatal rat ventricular cardiac myocytes cultured on collagen sponges in static dishes expressed multiple sarcomeres (Li et al., 1999) and formed spontaneously contracting constructs responding to calcium and epinephrine (Kofidis et al., 2002, Leor et al., 2000). However, diffusion alone was only able to satisfy the oxygen demand of the outer layer $(\sim 100 \mu \mathrm{m})$ of compact tissue at physiologic cell density (Carrier et al., 2002b), such that the interior of the constructs remained mostly acellular and the glucose metabolism was prevalently anaerobic (Radisic et al., 2003). Clearly, the presence of dead and apoptotic cells in the construct interior and the anaerobic cell metabolism are not physiologic and likely to cause aberration of the cell behavior from that observed in vivo.

Cultivation in systems involving the mixing and flow of culture medium around the constructs, such as mixed flasks and rotating bioreactors (Carrier et al., 1999), enhanced mass transport at tissue surfaces but the main mode of oxygen and nutrient transport within the construct remains molecular diffusion, like in static cultures. Mixing increased construct cellularity (4-fold) and metabolic activity (3-fold), resulted in more aerobic glucose metabolism (lactate yield on glucose was $1.5 \mathrm{~mol} / \mathrm{mol}$ with mixing and >2 $\mathrm{mol} / \mathrm{mol}$ without mixing), improved construct ultrastructure and significantly enhanced the expression of cardiac markers (Carrier et al., 1999). Electrophysiological studies conducted using a linear array of extracellular electrodes showed that the peripheral layer of the constructs exhibited relatively homogeneous electrical properties and sustained macroscopically continuous impulse propagation on a centimeter-size scale (Bursac et al., 1999). However, these properties were observed only within a $100 \mu \mathrm{m}$ thick layer of compact tissue at the constructs surface.

In contrast, perfusion of culture medium through the construct markedly improved its properties (Radisic et al., 2004d). After seven days of cultivation, the viability of cells in perfused constructs was indistinguishable from that of freshly isolated cells ( $85 \%$ ), as compared to the rather low viability of constructs cultured in mixed dishes ( $45 \%$ ). The molar ratio of lactate produced to glucose consumed in perfused constructs (L/G 1) indicated completely aerobic cell metabolism, in contrast to anearobically metabolizing (L/G 2) dish-grown constructs. Perfused constructs and native ventricles had more cells in the $S$ phase than in the G2/M phases, indicating that cells from dishgrown constructs were unable to complete the cell cycle and accumulated in the G2/M phase. Cells expressing cardiac differentiation markers (sarcomeric $\alpha$-actin, cardiac troponin I, sarcomeric tropomyosin) were present throughout the perfused constructs, while the dish-grown constructs had most cells located within a $100 \mu \mathrm{m}$ thick surface layer around an empty interior. In response to electrical stimulation, perfused constructs contracted synchronously, had lower excitation thresholds and recovered their baseline function levels following treatment with a gap junctional blocker; dish-grown constructs exhibited arrhythmic contractile patterns and failed to recover their baseline levels.

To provide oxygen transport similar to a capillary network, neonatal rat heart cells were perfused with culture medium on highly porous, soft elastomer scaffolds that contained an array of parallel channels made using a laser cutting/engraving system (Fig 4 A, C, D). To mimic oxygen levels supplied by hemoglobin, culture medium was supplemented with $10 \%$ v/v PFC emulsion (OxygentTM, kindly donated by Alliance Pharmaceuticals, San Diego CA); constructs perfused with un-supplemented culture medium served as controls (Fig 4B). Constructs were perfused unidirectionally at a flow rate of $0.1 \mathrm{~mL} / \mathrm{min}$ with a multi-channel peristaltic pump. As the medium flowed through the channel array, oxygen was depleted from the aqueous phase of the culture medium through diffusion into the construct space where it was used for cell respiration. Depletion of oxygen in the aqueous phase was the driving force for the diffusion of dissolved oxygen from the PFC particles, thereby maintaining overall higher oxygen concentrations in the medium. For comparison, in un-supplemented culture medium, oxygen was depleted faster since there was no oxygen carrier phase to act as a reservoir (Radisic et al., 2004a).

In PFC-supplemented medium, the decrease in the partial pressure of oxygen in the aqueous phase was only $62 \%$ of that in the control medium ( $28 \mathrm{mmHg}$ vs. $45 \mathrm{mmHg}$ between the construct inlet and outlet at the flow rate of $0.1 \mathrm{ml} / \mathrm{min}$ ). Consistently, constructs cultivated in the presence of PFC had higher amounts of DNA, troponin I and Cx-43 and significantly better contractile properties than control constructs. In both groups, cells were present at the channel surfaces as well as within constructs. In short, an enhanced supply of oxygen to the cells improved constructs properties.

\section{Excitation-contraction coupling}

In vivo, contraction of cardiac muscle is driven by waves of electrical excitation generated by pacing cells that spread rapidly along the membranes of adjoining cardiac myocytes and trigger the release of calcium, which in turn stimulates contraction of the myofibrils. In vitro, the establishment of functional connections between the cells cultured on scaffolds can be stimulated by applying electrical signals similar to those in the native heart (Radisic et al., 2004c), or by applying direct mechanical stimulation (Zimmermann et al., 2002b). In either case, it is essential that the cells become electromechanically coupled and capable of synchronously responding to electrical pacing signals, rather than contracting spontaneously.

In one approach, neonatal rat cardiac cells were resuspended in the collagen/Matrigel mix and cast into circular molds (Zimmermann et al., 2002b). After 7 days of static culture, the strips of cardiac tissue were placed around two rods of a custom made mechanical stretcher and subjected to either unidirectional or cyclic stretch. Histology and immunohistochemistry revealed formation of intensively interconnected, longitudinally oriented cardiac muscle bundles with morphological features resembling adult rather than immature native tissue. Fibroblasts, macroph- 
ages and capillary structures positive for CD31 were detected. Cardiomyocytes exhibited well developed ultrastructural features: sarcomeres arranged in myofibrils, pronounced $\mathrm{Z}, \mathrm{I}, \mathrm{A} \mathrm{H}$ and $M$ bands, specialized cell-cell junctions, $T$ tubules and well developed basement membrane. Contractile properties were similar to those measured for native tissue, with a high ratio of twitch to resting tension and strong $\beta$-adrenegenic response.

A
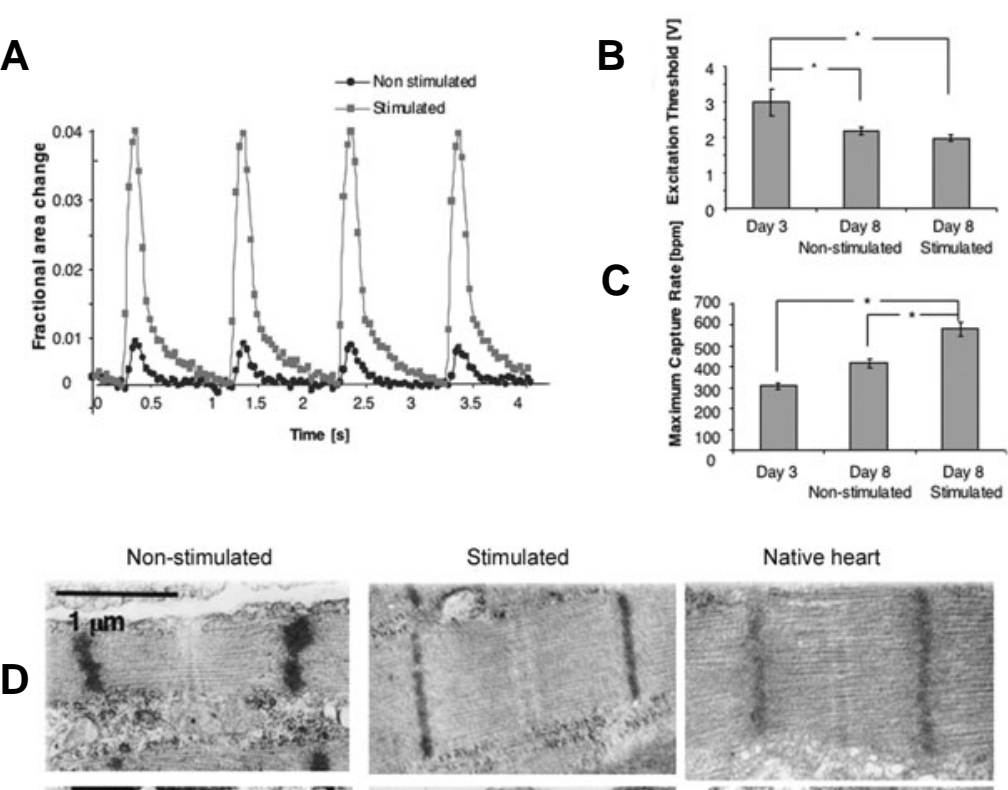

E

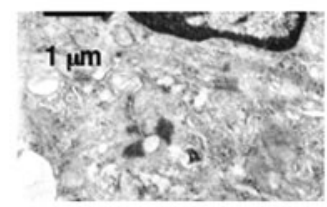

Non-stimulated
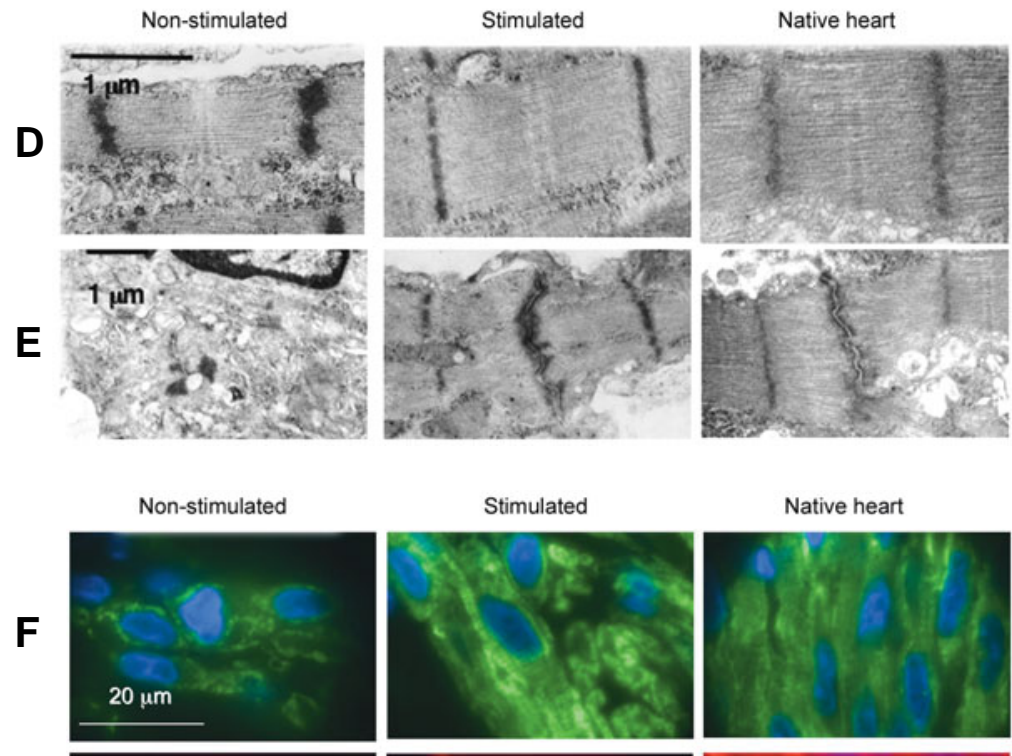

G
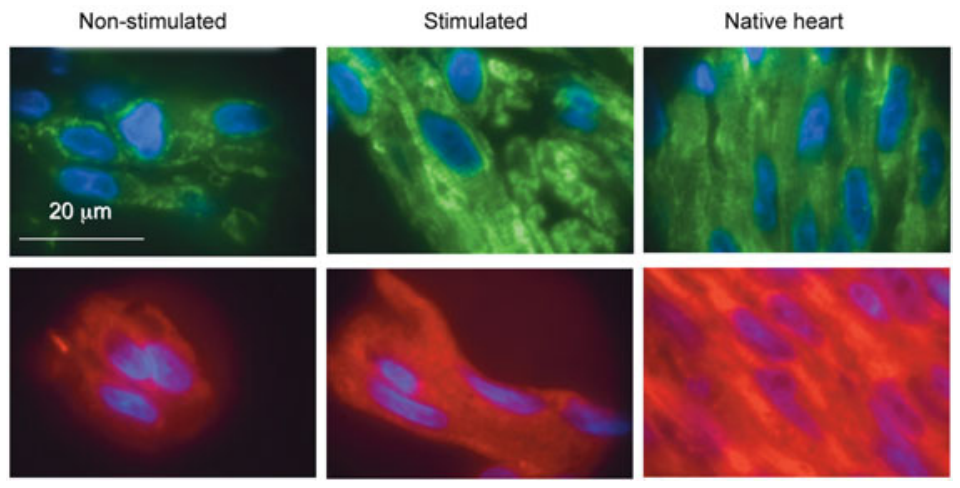

Fig. 5. Effects of electrical stimulation on functional assembly of engineered cardiac constructs. (A) Contraction amplitude of constructs cultured for a total of 8 days, shown as a fractional change in the construct size. Electrical stimulation increased the amplitude of contractions by a factor of seven. (B) Excitation threshold (ET) decreased and (C) Maximum capture rate (MCR) increased significantly both with time in culture and due to electrical stimulation. (*) denotes $^{*}$ statistically significant differences $(P<0.05$; Tukey's post-hoc test with one-way ANOVA, $n=5-10$ samples per group and time point). (D) The structure of sarcomeres and (E) gap junctions observed in micrographs of stimulated constructs after 8 days of cultivation were remarkably similar to neonatal rat ventricles and markedly better developed than in control (non-stimulated) constructs. Representative sections of constructs stained for $(\mathbf{F}) \mathrm{CX}-43$ (green) and (G) $\alpha-\mathrm{MHC}$ (red); cell nuclei are shown in blue. (Adapted from Radisic et al., 2004a)
Action potentials characteristic of rat ventricular myocytes were recorded. In a separate study, cyclic mechanical stretch $(1.33 \mathrm{~Hz})$ was applied to the constructs based on collagen scaffold (Gelfoam) and human heart cells (isolated from children undergoing repair of Tetralogy of Fallon) (Akhyari et al., 2002). Constructs subjected to chronic stretch had improved cell distributions, collagen matrix ormation and increased cell proliferation.

In another approach, constructs prepared by seeding collagen sponges $(6 \mathrm{~mm} \times 8 \mathrm{~mm} \times 1.5 \mathrm{~mm}$ ) with neonatal rat ventricular cells were stimulated using supra-threshold square biphasic pulses ( $2 \mathrm{~ms}$ duration, $1 \mathrm{~Hz}, 5 \mathrm{~V}$ ). Our decision to apply electrical stimulation to cultured constructs was again motivated by analogy to the in vivo situation. In native heart, mechanical stretch is induced by electrical signals and the orderly coupling between electrical pacing signals and macroscopic contractions is crucial for the development and function of native myocardium (Severs, 2000). The stimulation was initiated 15 days after scaffold seeding (with 3 days being optimal) and applied for up to eight days. Stimulation resulted in significantly better contractile responses to pacing as compared to un-stimulated controls, as evidenced by the 7-fold higher amplitude of contractions (Fig. 5A), lower excitation threshold (Fig. 5B) and higher maximum capture rate (Fig. 5C). Excitation-contraction coupling of cardiac myocytes in stimulated constructs was also evidenced by transmembrane potentials that were similar to the action potentials reported for cells from mechanically stimulated constructs (Zimmermann et al., 2002b).

Stimulated constructs exhibited higher levels of $\alpha$ myosin heavy chain ( $\alpha-\mathrm{MHC}), \mathrm{Cx}-43$, creatin kinase-MM and cardiac troponin I expression and contained thick aligned myofibers that resembled myofibers in the native heart. At the ultrastructural level, cells in stimulated constructs exhibited specialized features characteristic of native myocardium (Fig. 5 D, E). Gap junctions, intercalated discs and microtubules were all markedly more frequent in the stimulated group compared to the non-stimulated group. Cells in stimulated constructs contained aligned myofibrils and well developed sarcomeres with clearly visible $M$ and $Z$ lines and $H, I$ and, $A$ bands. In most cells, $Z$ lines were aligned and the intercalated discs were positioned between two $Z$ lines. In contrast, non-stimulated constructs had poorly developed cardiac-specific organelles and poor organization of ultrastructural features.

On a molecular level, electrical stimulation elevated the levels of all measured cardiac proteins and enhanced the expression of the corresponding genes, without causing pathological cell hypertrophy (Di Nardo et al., 1993). With time in culture, the ratio of mature to immature forms of myosin heavy chain ( $\alpha-\mathrm{MHC}$ and $\beta-\mathrm{MHC}$, respectively) decreased in non-stimulated and increased in stimulated constructs, suggesting that the maturation of cardiomyocytes depended both on culture duration and electrical stimulation (Fig. 5 E,F).

Overall, electrical stimulation of construct contractions during cultivation progressively enhanced the excitation-contraction coupling and improved the properties 
of engineered myocardium at the cellular, ultrastructural and tissue levels.

\section{Cardiac tissue engineering based on stem cells}

Like many specialized cells, cardiac cells are terminally differentiated, do not proliferate and therefore cannot regenerate damaged tissue. An innovative approach to heart repair comes from the hematopoietic field where bone marrow derived stem cells have been successfully used to treat diseases like leukemia. One option is to increase the number of endogenous stem cells with cytokine stimulation and then mobilize the cells to migrate to the injured site. Another option would be the direct delivery of cells to the damaged heart, a procedure feasible only if cardiogenic stem cells can be isolated, expanded and safely reintroduced into the heart. Three studies have independently identified primitive cells from the adult heart that are capable of dividing and developing into mature cardiac and vascular cells (Beltrami et al., 2003, Messina et al., 2004, Oh et al., 2003). A recent study revealed relatively unspecialized population of cells capable of maintaining their own population as well as giving rise to functional heart cells (Laugwitz et al., 2005). These cells populate the embryonic, fetus and postnatal heart and were successfully cultured in vitro, signifying their potential for use in cardiac transplantation therapy. Cardiac stem cells can also be grown from human biopsies as aggregates in suspension culture (Messina et al., 2004). These so-called cardiospheres contain a mixture of cardiac cell types and, when transplanted into mice after an acute heart attack, they formed vascular cells and heart muscle cells, albeit at a rather low frequency.

Human embryonic stem cells are another significant source of cells for cardiac transplantation because they can develop into almost any cell type, including cardiomyocytes (Thomson et al., 1998). It was demonstrated that differentiation was not limited to the generation of isolated cardiac cells, but rather functional cardiac syncytium could be made with stable pacemaker activity and electrical propagation (Kehat et al., 2004) and responding to adrenergic and cholinergic stimuli. The ability to generate different subtypes of human cardiomyocytes (with pacemaking-, atrial, ventricular-, or Purkinje-like phenotypes) that lend themselves to genetic manipulation may be of great value for future strategies of heart repair.

To engineer a functional cardiac graft, one would need to direct the cells to re-establish the structure and function of the tissue being replaced across different hierarchical scales. Biophysical regulation of the cells in vitrois essentially an effort to recapitulate multiple signals present during the development of the native heart. Dissociated heart cells (a mixed population of cardiomyocytes, endothelial cells and fibroblasts) cultured on three-dimensional scaffolds and subjected to signals inherent for the development and function of normal heart (such as electrical pacing signals) underwent functional assembly into cardiac-like tissue. Notably, the development of conductive and contractile properties of cardiac constructs was concurrent and depended on the initiation and duration of electrical stimulation.

To engineer a cardiac graft starting from human stem cells, the culture system should be capable of first inducing cel/ differentiationand then the functional assembly of differentiated cells. Given that there are multiple regulatory signals (molecular and physi- cal), which interact according to specific spatial and temporal patterns, a culture system for stem-cell based cardiac tissue engineering should have sufficiently high fidelity to provide the environmental control and biophysical regulation of cultured cells. Our most advanced existing bioreactors can provide eitherlocal control of oxygen and $\mathrm{pH}$ (via medium perfusion through channeled scaffolds and the use of oxygen carriers), orphysical stimuli (via electrical stimulation of contractile function). A system providing both factors simultaneously, is likely to be essential for extending the methods of cardiac tissue engineering to the use of human stem cells. An additional advantage of this system is that it could serve as a model for rigorous studies of cardiac development and function. The bioreactor can serve not only as a means to provide environmental control and stimuli but also as a tool to identify the relative importance of each stimulus, when it should be applied and at which level. As an example, consider only electrical stimulation with a square biphasic pulse. The variables of interest are the pulse width, pulse amplitude, frequency, initiation of stimulus and duration of stimulus. A full factorial design on these five parameters leads to 32 possible combinations at two levels and 243 combinations at three levels. Clearly, conducting this many experiments with existing systems is neither practical nor desirable. To answer these questions, novel bioreactor designs are required that increase the number of experiments which can be performed. In this regard, we anticipate that microfluidic (e.g., PDMS) and BioMEMS techniques will be invaluable.

\section{Summary}

In summary, to engineer myocardium, biophysical regulation of the cells needs to recapitulate multiple signals present in the native heart. The biomimetic approach to tissue engineering reviewed here focuses on three specific aspects that are critical for the development and-function of native myocardium: cell signaling (by culturing subpopulations of cardiac cells on a highly porous, elastic scaffold at physiologically high spatial density), convective-diffusive oxygen transport by blood flow (by the use of channeled scaffolds perfused with culture medium containing oxygen carriers) and excitation-contraction coupling (by inducing contractions of cultured constructs with cardiac-like electrical signals). Each of these three factors contributed to cell assembly into tissue constructs with molecular, structural and functional properties resembling those of native myocardium after only eight days of in vitro cultivation. In ongoing studies, we are testing the functionality and vascularization of these cardiac constructs in an animal model and extending the same approach to the cultivation of functional cardiac tissue grafts starting from human stem cells. Overall, the proposed approach shows great potential for cardiac tissue engineering, but much more needs to be done to demonstrate the clinical utility of engineered cardiac grafts.

\section{Acknowledgments}

The work presented in this paper has been supported by the National Aeronautics and Space Administration (NNJ04HC72G, GV-N, MR, HP), the National Institutes of Health (1-P41-EB002520-01A1 to GV-N and CC; R01HL076485 to GV-N), Poitras Fellowship (MR) and Juvenile Diabetes Research Foundation (SG). The authors would like to thank Sue Kangiser for her help with manuscript preparation and to Aliance Pharmaceuticals for kindly providing oxygen carriers. 


\section{References}

AKHYARI, P., FEDAK, P.W.M., WEISEL, R.D., LEE, T.Y.J., VERMA, S., MICKLE, D.A.G. and LI, R.K. (2002). Mechanical stretch regimen enhances the formation of bioengineered autologous cardiac muscle grafts. Circulation. 106:1137-1142.

AKINS, R.E., BOYCE, R.A., MADONNA, M.L., SCHROEDL, N.A., GONDA, S.R., MCLAUGHLIN, T.A. and HARTZELL, C.R. (1999). Cardiac organogenesis in vitro: Reestablishment of three-dimensional tissue architecture by dissociated neonatal rat ventricular cells. Tissue Eng. 5:103-118.

ANTIN, P.B., TAYLOR, R.G. and YATSKIEVYCH, T. (1994). Precardiac mesoderm is specified during gastrulation in quail. Dev. Dyn. 200:144-154.

ANTIN, P.B., YATSKIEVYCH, T., DOMINGUEZ, J.L. and CHIEFFI, P. (1996). Regulation of avian precardiac mesoderm development by insulin and insulin-like growth factors. J. Cell. Physiol. 168:42-50.

BELTRAMI, A.P., BARLUCCHI, L., TORELLA, D., BAKER, M., LIMANA, F., CHIMENTI, S., KASAHARA, H., ROTA, M., MUSSO, E., URBANEK, K., LERI, A., KAJSTURA, J., NADAL-GINARD, B. and ANVERSA, P. (2003). Adult cardiac stem cells are multipotent and support myocardial regeneration. Cell. 114:763-776.

BRAUNWALD, E. and PFEFFER, M.A. (1991). Ventricular enlargement and remodeling following acute myocardial infarction: mechanisms and management. Am. J. Cardiol. 68:1D-6D.

BRILLA, C.G., MAISCH, B., RUPP, H., SUNCK, R., ZHOU, G. and WEBER, K.T. (1995). Pharmacological modulation of cardiac fibroblast function. Herz. 20:127135.

BURSAC, N., PAPADAKI, M., COHEN, R.J., SCHOEN, F.J., EISENBERG, S.R., CARRIER, R., VUNJAK-NOVAKOVIC, G. and FREED, L.E. (1999). Cardiac muscle tissue engineering: toward an in vitro model for electrophysiological studies. Am. J. Physiol. Heart Circ. Physiol. 277:H433-H444.

CARRIER, R.L., PAPADAKI, M., RUPNICK, M., SCHOEN, F.J., BURSAC, N., LANGER, R., FREED, L.E. and VUNJAK-NOVAKOVIC, G. (1999). Cardiac tissue engineering: cell seeding, cultivation parameters and tissue construct characterization. Biotechnol. Bioeng. 64:580-589.

CARRIER, R.L., RUPNICK, M., LANGER, R., SCHOEN, F.J., FREED, L.E. and VUNJAK-NOVAKOVIC, G. (2002a). Effects of oxygen on engineered cardiac muscle. Biotechnol. Bioeng. 78:617-625.

CARRIER, R.L., RUPNICK, M., LANGER, R., SCHOEN, F.J., FREED, L.E. and VUNJAK-NOVAKOVIC, G. (2002b). Perfusion improves tissue architecture of engineered cardiac muscle. Tissue Eng. 8:175-188.

CHENG, W., KAJSTURA, J., NITAHARA, J.A., LI, B., REISS, K., LIU, Y., CLARK, W.A., KRAJEWSKI, S., REED, J.C., OLIVETTI, G. and ANVERSA, P. (1996). Programmed myocyte cell death affects the viable myocardium after infarction in rats. Exp. Cell Res. 226:316-327.

CLIMENT, S., SARASA, M., VILLAR, J.M. and MURILLO-FERROL, N.L. (1995). Neurogenic cells inhibit the differentiation of cardiogenic cells. Dev. Biol. 171:130148.

DI NARDO, P., MINIERI, M., CARBONE, A., MAGGIANO, N., MICHELETTI, R., PERUZZI, G. and TALLARIDA, G. (1993). Myocardial expression of atrial natriuretic factor gene in early stages of hamster cardiomyopathy. Mol. Cell. Biochem. 125:179-192.

ESCHENHAGEN, T., FINK, C., REMMERS, U., SCHOLZ, H., WATTCHOW, J., WOIL, J., ZIMMERMANN, W., DOHMEN, H.H., SCHAFER, H., BISHOPRIC, N., WAKATSUKI, T. and ELSON, E. (1997). Three-dimensional reconstitution of embryonic cardiomyocytes in a collagen matrix: a new heart model system. FASEB J. 11:683-694.

ETZION, S., BATTLER, A., BARBASH, I.M., CAGNANO, E., ZARIN, P., GRANOT, Y., KEDES, L.H., KLONER, R.A. and LEOR, J. (2001). Influence of embryonic cardiomyocyte transplantation on the progression of heart failure in a rat model of extensive myocardial infarction. J. Mol. Cell. Cardiol. 33:1321-30.

FINK, C., ERGUN, S., KRALISCH, D., REMMERS, U., WEIL, J. and ESCHENHAGEN, T. (2000). Chronic stretch of engineered heart tissue induces hypertrophy and functional improvement. FASEB J. 14:669-679.

FISHMAN, M.C. and CHIEN, K.R. (1997). Fashioning the vertebrate heart: earliest embryonic decisions. Development. 124:2099-2117.

FOURNIER, R.L. (1998). Basic Transport Phenomena in Biomedical Engineering Taylor \& Francis, Philadelphia.
GEPSTEIN, L., FELD, Y. and YANKELSON, L. (2004). Somatic gene and cell therapy strategies for the treatment of cardiac arrhythmias. Am. J. Physiol. Heart Circ. Physiol. 286:H815-H822.

GILBERT, S.F., TYLER, M.S. and KOZLOWSKI, R.N. (2000). Developmentalbiology (6th edn.). Sinauer Associates, Sunderland, Mass.

GUDI, S.R., LEE, A.A., CLARK, C.B. and FRANGOS, J.A. (1998). Equibiaxial strain and strain rate stimulate early activation of $\mathrm{G}$ proteins in cardiac fibroblasts. $\mathrm{Am}$. J. Physiol. 274:C1424-C1428.

HARVEY, R.P. (1998). Links in the left/right axial pathway. Cell. 94:273-276.

HEIKINHEIMO, M., SCANDRETT, J.M. and WILSON, D.B. (1994). Localization of transcription factor GATA-4 to regions of the mouse embryo involved in cardiac development. Dev. Biol. 164:361-373.

HUNT, S.A. (1998). Current status of cardiac transplantation. J.A.M.A. 280:16921698.

INGBER, D.E. (2002). Mechanical signaling and the cellular response to extracellular matrix in angiogenesis and cardiovascular physiology. Circ. Res. 91:877-887.

JIANG, Y. and EVANS, T. (1996). The Xenopus GATA-4/5/6 genes are associated with cardiac specification and can regulate cardiac-specific transcription during embryogenesis. Dev. Biol. 174:258-270.

KEHAT, I., KHIMOVICH, L., CASPI, O., GEPSTEIN, A., SHOFTI, R., ARBEL, G., HUBER, I., SATIN, J., ITSKOVITZ-ELDOR, J. and GEPSTEIN, L. (2004). Electromechanical integration of cardiomyocytes derived from human embryonic stem cells. Nat. Biotechnol. 22:1282-1289.

KOFIDIS, T., AKHYARI, P., BOUBLIK, J., THEODOROU, P., MARTIN, U., RUHPARWAR, A., FISCHER, S., ESCHENHAGEN, T., KUBIS, H.P., KRAFT, T., LEYH, R. and HAVERICH, A. (2002). In vitro engineering of heart muscle: Artificial myocardial tissue. J. Thorac. Cardiovasc. Surg. 124:63-69.

LARSEN, W.J. (1998). Essentials of humanembryology(2nd edn.). Churchill Livingsone Inc., New York.

LAUGWITZ, K.L., MORETTI, A., LAM, J., GRUBER, P., CHEN, Y., WOODARD, S., LIN, L.Z., CAI, C.L., LU, M.M., RETH, M., PLATOSHYN, O., YUAN, J.X., EVANS, S. and CHIEN, K.R. (2005). Postnatal isl1+ cardioblasts enter fully differentiated cardiomyocyte lineages. Nature. 433:647-653.

LAVERRIERE, A.C., MACNEILL, C., MUELLER, C., POELMANN, R.E., BURCH, J.B. and EVANS, T. (1994). GATA-4/5/6, a subfamily of three transcription factors transcribed in developing heart and gut. Biol. Chem. 269:23177-23184.

LEE, M.S. and MAKKAR, R.R. (2004). Stem-cell transplantation in myocardial infarction: a status report. Ann. Intern. Med. 140:729-737.

LEOR, J., PATTERSON, M., QUINONES, M., KEDES, L. and KLONER, R. (1996) Transplantation of fetal myocardial tissue into the infarcted myocardium of rat. Circulation. 94:II-322 - II-336.

LEOR, J., ABOULAFIA-ETZION, S., DAR, A., SHAPIRO, L., BARBASH, I.M., BATTLER, A., GRANOT, Y. and COHEN, S. (2000). Bioengineerred cardiac grafts: A new approach to repair the infarcted myocardium? Circulation. 102:III56III61.

LI, R.-K., JIA, Z.Q., WEISEL, R.D., MICKLE, D.A.G., CHOI, A. and YAU, T.M. (1999). Survival and function of bioengineered cardiac grafts. Circulation. 100:II63-II69.

LI, R.-K., YAU, T.M., WEISEL, R.D., MICKLE, D.A.G., SAKAI, T., CHOI, A. and JIA Z.-Q. (2000). Construction of a bioengineered cardiac graft. J. Thorac. CardiovasC. Surg. 119:368-375.

LOUGH, J. and SUGI, Y. (2000). Endoderm and heart development. Dev. Dyn. 217:327-342.

MACKENNA, D.A., OMENS, J.H., MCCULLOCH, A.D. and COVELL, J.W. (1994) Contribution of collagen matrix to passive left ventricular mechanics in isolated rat heart. Am. J. Physiol. 266:H1007-H1018.

MACKENNA, D.A., DOLFI, F., VUORI, K. and RUOSLAHTI, E. (1998). Extracellular signal-regulated kinase and c-Jun $\mathrm{NH} 2$-terminal kinase activation by mechanical stretch is integrin-dependent and matrix-specific in rat cardiac fibroblasts. J. Clin. Invest. 101:301-310.

MALY, I.V., LEE, R.T. and LAUFFENBURGER, D.A. (2004). A model for mechanotransduction in cardiac muscle: effects of extracellular matrix deformation on autocrine signaling. Ann. Biomed. Eng. 32:1319-1335.

MANDARIM-DE-LACERDA, C.A. and PEREIRA, L.M.M. (2000). Numerical density of cardiomyocytes in chronic nitric oxide synthesis inhibition. Pathobiology. 68:3642. 
MENASCHE, P., HAGEGE, A.A., SCORSIN, M., POUZET, B., DESNOS, M., DUBOC, D., SCHWARTZ, K., VILQUIN, J.T. and MAROLLEAU, J.P. (2001). Myoblast transplantation for heart failure. Lancet. 357:279-280.

MENASCHE, P. (2003). Skeletal muscle satellite cell transplantation. Cardiovasc. Res. 58:351-357.

MESSINA, E., DE ANGELIS, L., FRATI, G., MORRONE, S., CHIMENTI, S., FIORDALISO, F., SALIO, M., BATTAGLIA, M., LATRONICO, M.V., COLETTA, M., VIVARELLI, E., FRATI, L., COSSU, G. and GIACOMELLO, A. (2004). Isolation and expansion of adult cardiac stem cells from human and murine heart. Circ. Res. 95:911-921.

OBERPENNING, F., MENG, J., YOO, J.J. and ATALA, A. (1999). De novo reconstitution of a functional mammalian urinary bladder by tissue engineering. Nat. Biotechnol. 17:149-155.

OGAWA, K., OCHOA, E.R., BORENSTEIN, J., TANAKA, K. and VACANTI, J.P. (2004). The generation of functionally differentiated, three-dimensional hepatic tissue from two-dimensional sheets of progenitor small hepatocytes and nonparenchymal cells. Transplantation. 77:1783-1789.

OH, H., BRADFUTE, S.B., GALLARDO, T.D., NAKAMURA, T., GAUSSIN, V., MISHINA, Y., POCIUS, J., MICHAEL, L.H., BEHRINGER, R.R., GARRY, D.J., ENTMAN, M.L. and SCHNEIDER, M.D. (2003). Cardiac progenitor cells from adult myocardium: homing, differentiation and fusion after infarction. Proc. Nat/. Acad. Sci. USA. 100:12313-12318.

OHJI, T., URANO, H., SHIRAHATA, A., YAMAGISHI, M., HIGASHI, K., GOTOH, S. and KARASAKI, Y. (1995). Transforming growth factor beta 1 and beta 2 induce down-modulation of thrombomodulin in human umbilican vein endothelial cells. Thromb. Haemost. 73:812-818.

OLSON, E.N. and SRIVASTAVA, D. (1996). Molecular pathways controlling heart development. Science. 272:671-676.

ORLIC, D., KAJSTURA, J., CHIMENTI, S., JAKONIUK, I. andERSON, S.M., LI, B., PICKEL, J., MCKAY, R., NADAL-GINARD, B., BODINE, D.M., LERI, A. and ANVERSA, P. (2001). Bone marrow cells regenerate infarcted myocardium. Nature. 410:701-705.

PAPADAKI, M., BURSAC, N., LANGER, R., MEROK, J., VUNJAK-NOVAKOVIC, G. and FREED, L.E. (2001). Tissue engineering of functional cardiac muscle: molecular, structural and electrophysiological studies. Am. J. Physiol. Heart Circ. Physiol. 280:H168-H178.

RADISIC, M., EULOTH, M., YANG, L., LANGER, R., FREED, L.E. and VUNJAKNOVAKOVIC, G. (2003). High density seeding of myocyte cells for tissue engineering. Biotechnol. Bioeng. 82:403-414.

RADISIC, M., DEEN, W., LANGER, R. and VUNJAK-NOVAKOVIC, G. (2005). Mathematical model of oxygen distribution in engineered cardiac tissue with parallel channel array perfused with culture medium supplemented with synthetic oxygen carriers. Am. J. Physiol. 288: H1278-H1289.

RADISIC, M., PARK, H., LANGER, R., FREED, L.E. and VUNJAK-NOVAKOVIC, G. (2004b). Co-culture of cardiac fibroblasts and myocytes enhances functional assembly of engineered myocardium. In Conference Proceedings, 7th International Congress of the Cell Transplant Society (CTS 2004), Boston, MA, November $17-20,2004 b$.

RADISIC, M., PARK, H., SHING, H., CONSI, T., SCHOEN, F.J., LANGER, R., FREED, L.E. and VUNJAK-NOVAKOVIC, G. (2004c). Functional assembly of engineered myocardium by electrical stimulation of cardiac myocytes cultured on scaffolds. Proc. Natl. Acad. Sci. USA. 101:18129-18134.

RADISIC, M., YANG, L., BOUBLIK, J., COHEN, R.J., LANGER, R., FREED, L.E. and VUNJAK-NOVAKOVIC, G. (2004d). Medium perfusion enables engineering of compact and contractile cardiac tissue. Am. J. Physiol. Heart Circ. Physiol. 286:H507-H516.

RAKUSAN, K. and KORECKY, B. (1982). The effect of growth and aging on functional capillary supply of the rat heart. Growth. 46:275-281.

RISAU, W. (1997). Mechanisms of angiogenesis. Nature. 386:671-674, Review.

ROSS, R.S., PHAM, C., SHAI, S.Y., GOLDHABER, J.I., FENCZIK, C., GLEMBOTSKI, C.C., GINSBERG, M.H. and LOFTUS, J.C. (1998). Beta1 integrins participate in the hypertrophic response of rat ventricular myocytes. Circ. Res. 82:1160-1172.

SCHRAM, G., POURRIER, M., MELNYK, P. and NATTEL, S. (2002). Differential distribution of cardiac ion channel expression as a basis for regional specialization in electrical function. Circ. Res. 90:939-950.

SCHULTHEISS, T.M., BURCH, J.B. and LASSAR, A.B. (1997). A role for bone morphogenetic proteins in the induction of cardiac myogenesis. Genes Dev. 11:451-462.

SCORSIN, M., MAROTTE, F., SABRI, A., LE DREF, O., DEMIRAG, M., SAMUEL, J.L., RAPPAPORT, L. and MEASCHE, P. (1996). Can grafted cardiomyocytes colonize peri-infarct myocardial areas? Circulation. 94:II337-II340.

SEVERS, N.J. (2000). The cardiac muscle cell. Bioessays. 22:188-199.

SHIMIZU, T., YAMATO, M., ISOI, Y., AKUTSU, T., SETOMARU, T., ABE, K., KIKUCHI, A., UMEZU, M. and OKANO, T. (2002). Fabrication of pulsatile cardiac tissue grafts using a novel 3- dimensional cell sheet manipulation technique and temperature- responsive cell culture surfaces. Circ. Res. 90:e40-e48.

SUGI, Y. and LOUGH, J. (1995). Activin-A and FGF-2 mimic the inductive effects of anterior endoderm on terminal cardiac myogenesis in vitro. Dev. Biol. 168:567574.

TAYLOR, D.A., ATKINS, B.Z., HUNGSPREUGS, P., JONES, T.R., REEDY, M.C., HUTCHESON, K.A., GLOWER, D.D. and KRAUS, W.E. (1998). Regenerating functional myocardium: improved performance after skeletal myoblast transplantation. Nat. Med. 4:929-933.

THOMSON, J.A., ITSKOVITZ-ELDOR, J., SHAPIRO, S.S., WAKNITZ, M.A., SWIERGIEL, J.J., MARSHALL, V.S. and JONES, J.M. (1998). Embryonic stem cell lines derived from human blastocysts. Science. 282:1145-1147.

VAN LUYN, M.J.A., TIO, R.A., VAN SEIJEN, X.J.G.Y., PLANTINGA, J.A., DE LEIJ, L.F.M.H., DEJONGSTE, M.J.L. and VAN WACHEM, P.B. (2002). Cardiac tissue engineering: characteristics of in unison contracting two- and three-dimensional neonatal rat ventricle cell (co)-cultures. Biomaterials. 23:4793-4801.

ZAFFRAN, S. and FRASCH, M. (2002). Early signals in cardiac development. Circ. Res. 91:457-469.

ZHU, X., SASSE, J., MCALLISTER, D. and LOUGH, J. (1996). Evidence that fibroblast growth factors 1 and 4 participate in regulation of cardiogenesis. Dev. Dyn. 207:429-438.

ZIMMERMANN, W.H., FINK, C., KRALISH, D., REMMERS, U., WEIL, J. and ESCHENHAGEN, T. (2000). Three-dimensional engineered heart tissue from neonatal rat cardiac myocytes. Biotechnol. Bioeng. 68:106-114.

ZIMMERMANN, W.H., DIDIE, M., WASMEIER, G.H., NIXDORFF, U., HESS, A., MELNYCHENKO, I., BOY, O., NEUHUBER, W.L., WEYAND, M. and ESCHENHAGEN, T. (2002a). Cardiac grafting of engineered heart tissue in syngenic rats. Circulation. 106:I151-I157.

ZIMMERMANN, W.H., SCHNEIDERBANGER, K., SCHUBERT, P., DIDIE, M., MUNZEL, F., HEUBACH, J.F., KOSTIN, S., NEHUBER, W.L. and ESCHENHAGEN, T. (2002b). Tissue engineering of a differentiated cardiac muscle construct. Circ. Res. 90:223-230. 